\title{
Omega-3 PUFA vs. NSAIDs for Preventing Cardiac Inflammation
}

\author{
Jiayu Ye and Sanjoy Ghosh* \\ Irving K. Barber School of Arts and Sciences (IKBSAS), Department of Biology, University of University of British Columbia, \\ Kelowna, BC, Canada
}

Keywords: inflammation, docosahexaenoic acid (DHA), EPA, aspirin, NSAIDs

\section{INTRODUCTION}

Inflammatory cell accumulation occurs in the cardiac muscle during cardiac injury and repair (1). From an evolutionary perspective, inflammation is required for immunosurveillance and host defense. However, such cardinal signs of acute inflammation, such as redness, pain, swelling etc., due to injury or infection. Might be typically absent in chronic low-grade inflammation (LGI). Current literature suggests that chronic low-grade inflammation (LGI) is a primary causative factor behind chronic diseases like cardiovascular diseases (CVD), non-alcoholic fatty liver disease (NAFLD) and obesity (2).

\section{COMMON MECHANISMS FOR NSAIDs}

NSAIDs are anti-inflammatory drugs which as a class block the generation of prostaglandins (PGs), leukotrienes (LT) or epoxides (3), which are upregulated during inflammation Therefore, NSAIDs are commonly used for prevention of multiple chronic inflammatory conditions including CVD. The major enzyme participating in PG biosynthesis is cyclooxygenase (COX), which is subdivided as constitutive COX-1 and inducible COX-2 forms. These isoforms of COX show differential activity in inflamed tissues. COX-2 is expressed 10- to 80 -fold, whereas COX-1 expressed 2- to 4 -fold (4). Both COX isoforms are responsible for converting arachidonic acid (ARA) to intermediate PGs, the $\mathrm{PGG}_{2}$, and the $\mathrm{PGH}_{2}$. ARA is the precursor of eicosanoids which is cleaved by phospholipase $\mathrm{A}_{2}\left(\mathrm{PLA}_{2}\right)$ from membrane phospholipids. Then thromboxane synthase and various isomerases are activated which generates thromboxane $\mathrm{A}_{2}$ (TxA2) and PGs $\left(\mathrm{PGE}_{2}\right.$, $\mathrm{PGF}_{2 \alpha}, \mathrm{PGD}_{2}, \mathrm{PGI}_{2}$ ) (5). These four PGs have the common function of vasodilation as well as increasing permeability of membranes (thus promoting "redness" due to increased blood flow). $\mathrm{PGE}_{2}$ and $\mathrm{PGF}_{2 \alpha}$ are mainly produced by monocytes and macrophages, mast cells produce $\mathrm{PGD}_{2}$ and endothelial cells produce $\mathrm{PGI}_{2}$ (6). Long-term treatment with NSAIDs lower beneficial PGs as well (7). $\mathrm{PGE}_{2}$ and $\mathrm{PGF}_{2 \alpha}$ control water and electrolyte absorption and maintain secretion in gastric mucosa. Thus, NSAIDs can decrease the secretion of mucous-bicarbonate barrier between the gastric lumen and epithelial cells. Subsequently, in contact with low $\mathrm{pH}$ of the stomach, epithelial cells are killed and the integrity of the mucosa is lost, causing ulceration (7).

\section{ASPIRIN}

Aspirin is a widely used anti-inflammatory drug. Aspirin inhibits the COX activity by acetylating the hydroxyl group on COX, which specific acts on serine residues. This leads to the irreversible inhibition of COX, as well as causes the ARA binding restriction (8).

Aspirin is easily and quickly absorbed in the GI tract and hydrolyzes to salicylic acid (SA) in the stomach and intestine. However, SA and aspirin can strongly bind to albumin. This avoids the hydrolysis of aspirin too fast (9), as albumin concentration often decreases dramatically doi: $10.3389 /$ fCvm.2018.00146 under acute inflammation due to the formation of complex albumin-hyaluronic acid or due 
to decreased albumin synthesis $(9,10)$. Thus, SA and aspirin hydrolyze faster under acute inflammation. In this case, regulating the range of SA (or aspirin dose) concentration is critical in order to avoid further adverse effects. The half-life of aspirin is relatively short, for $15-20 \mathrm{~min}$ in adults. Aspirin inhibits the PGs production mainly due to the blockage of COX-2. However, aspirin also inhibits the cytoprotective PGs in gastric mucosa, which impairs the integrity of epithelial cells and also destabilizes the lysosomal membrane (11).

\section{INDOMETHACIN}

Indomethacin is a NSAID, and is effective against fever and pain. Like aspirin, indomethacin is a non-selective NSAIDs, which block both COX-1 and COX-2 (12). Thus, PGE 1 and $\mathrm{PGE}_{2}$ in gastric mucosa can be reduced, resulting in gastric and intestinal ulceration (11). Similarly, with the inhibitory effect of $\mathrm{TxA}_{2}$, the platelet aggregation ability decreases dramatically to induce bleeding (13). Studies also show that indomethacin can potentially increase the blood pressure in patients (14). It is easily absorbed by the GI tract and bind with the protein in plasma and injured tissues, specifically albumin as aspirin.

\section{IBUPROFEN}

Ibuprofen is an effective analgesic and an antipyretic and especially recommended for children because of its better safety profile. Ibuprofen needs longer time than other NSAIDs as an antipyretic and it has a more intense effect on pain relief than aspirin (15). The advantage of this drug is the lighter side effects on the GI tract. High dose for long-term use is mainly for the chronic inflammatory diseases, including arthritis (15).

\section{RECENT PROBLEMS WITH USING NSAIDS IN CARDIAC DISEASES}

NSAIDs like aspirin has been used for decades to protect against low grade inflammation in cardiovascular disorders. It was initially thought to be safe and effective against systemic inflammation affecting the cardiovascular system $(16,17)$. However, evidence of benefit as not been consistent (18) and is plagued by major side effects like GI bleeding, which can make this therapeutic approach questionable in vulnerable populations (19). In essence, a core impact of NSAIDs is to inhibit COX activity. However, COX activity, especially COX-2, is responsible for also maintaining aorta function. COX2 disruption can harden aorta leading to aortic fibrosis (20) and atheroclerosis (21). In addition, inhibition of COX 2 reduces the benefits of statin on cardioprotection (22). This might be the reason why all NSAIDs like ibuprofen and naproxen in addition to aspirin in recent years have demonstrated cardiovascular effects including heart attacks $(23,24)$. More importantly, according to a recent study, long-term users of aspirin have $>30 \%$ increased chance of a cardiovascular event upon withdrawal of the drug (25). Therefore, preventative therapies that avoid long term NSAID use is warranted in chronic inflammatory diseases including CVDs.

\section{OMEGA-3 PUFA}

Omega-3 PUFA are polyunsaturated fatty acids with the first double bond on the third carbon from the terminal methyl end. Fish and flaxseed oils are rich in omega-3 PUFA with protective functions for the heart (26), liver (27), and brain (28). The major fatty acids contained in the fish oil supplement are eicosapentaenoic acid (EPA) and docosahexaenoic acid (DHA), the long chain members of the omega-3 family. In contrast, flaxseed oil is mainly composed of alpha-linolenic acid (ALA), the parent omega-3 PUFA.

\section{MECHANISM OF ANTI-INFLAMMATORY RESPONSE}

Similar to NSAIDs, omega-3 PUFA, especially EPA and DHA inhibit the production of pro-inflammatory eicosanoids. However, instead of blocking COX activity, they use the same COX to increase the production of anti-inflammatory eicosanoids by providing a different substrate. Twenty-carbon omega-3 PUFA and ARA compete with each other for the use of the COX enzyme. This increases the production of the antiinflammatory mediators like $\mathrm{LTB}_{5}$ and $\mathrm{PGE}_{3}$ from EPA and at the same time limits the inflammatory $\mathrm{LTB}_{4}$ and $\mathrm{PGE}_{2}$ production from ARA (29). In this case, the mucosa protective PGs $\left(\mathrm{PGE}_{2}\right)$ are still available, albeit reduced. As a result, the side effects caused by anti-inflammatory drugs are drastically reduced. Given the basic differences in the mechanism of NSAIDs and omega3 PUFAs in blocking COX vs. providing an alternate substrate to COX enzyme, the timeline for actions are vastly different. NSAIDs are more acute in action due to direct enzymatic blockade, whereeas omega-3 PUFAs act slower due to its gradual replacement of membrane phospholipid ARA, which might take weeks if not months to have a biologically plausible effect. Clearly, NSAIDs are preferred for acute inflammatory challenges resulting from physical injury or trauma whereas omega-3 PUFAs are at best a long term, mild anti-inflammatory solution. Thus, consuming omega-3 supplement can be considered as a preventative therapy, alternate to NSAIDs on resolving longterm chronic inflammatory stage, with some major differences as listed in Table 1 (65).

In addition to modulating PGs, EPA and DHA produce lipid mediators responsible for anti-inflammation and resolution: resolvins and protectins (66). Due to the different substrates of resolvins' production, they are divided into E-series from EPA and D-series from DHA (66). Although they are from different sources, they show very similar effects on preventing inflammation. Both of them increase with the presence of aspirin or with higher EPA/DHA consumption, which are stimulated by the aspirin acetylated COX-2. As mentioned before, COX-2 is the rate-limiting enzyme promoting the synthesis of pro and antiinflammatory eicosanoids, depending on the different substrates. COX-2 dependent resolvins attenuate inflammation and block 
TABLE 1 | Comparison of anti-inflammatory role between omega-3 PUFA and NSAIDs.

\begin{tabular}{|c|c|c|}
\hline & Omega-3 PUFA & NSAIDs \\
\hline Main effect & $\begin{array}{l}\text { Reducing inflammatory } \\
\text { eicosanoids production (30) }\end{array}$ & $\begin{array}{l}\text { Blocking inflammatory } \\
\text { eicosanoids production ( } 31 \text { ) }\end{array}$ \\
\hline Mechanism & $\begin{array}{l}\text { Compete with ARA for COX } \\
\text { binding sites (30) }\end{array}$ & $\begin{array}{l}\text { Broadly block COXs activity } \\
\text { (31) }\end{array}$ \\
\hline Lipid profile & $\downarrow T C, \downarrow T G, \downarrow L D L, \uparrow H D L(32)$ & $\begin{array}{l}\uparrow L D L, \uparrow T G, \uparrow T C, \downarrow H D L \\
(33,34)\end{array}$ \\
\hline $\begin{array}{l}\text { Blood } \\
\text { pressure }\end{array}$ & $\downarrow(35)$ & $\uparrow(36,37)$ \\
\hline Cytokine & $\begin{array}{l}\downarrow I L-1 \text { (38), } \downarrow \text { TNF } \alpha \text { (38), } \\
\downarrow I L-6(39)\end{array}$ & $\downarrow \| L-1, \downarrow T N F \alpha, \downarrow I L-6$ (40) \\
\hline ROS & $\downarrow(41)$ & $\uparrow(42)$ \\
\hline $\begin{array}{l}\text { Low-dose } \\
\text { effect* }\end{array}$ & $\begin{array}{l}\text { Slowing renal dysfunction } \\
\text { (43) } \\
\text { Reduce seizure and improve } \\
\text { epilepsy (44) } \\
\text { Improvement on mild to } \\
\text { moderate depression (45) } \\
\text { Decreased oxidative stress } \\
\text { in type } 2 \text { diabetes (46) }\end{array}$ & $\begin{array}{l}\text { Primary Cardiovascular } \\
\text { Diseases Prevention (47) } \\
\text { cerebrovascular disease } \\
\text { prevention (48) } \\
\text { analgesic effect on dental } \\
\text { pain(49) and osteoarthritis } \\
\text { pain (50) } \\
\text { inhibitory effect on tumor } \\
\text { cell growth and metastasis } \\
\text { (51) } \\
\text { Intraventricular Hemorrhage } \\
\text { prevention (52) }\end{array}$ \\
\hline $\begin{array}{l}\text { High-dose } \\
\text { effect* }^{*}\end{array}$ & $\begin{array}{l}\text { Substitution of NSAIDs in } \\
\text { rheumatoid arthritis (53) } \\
\text { Secondary prevention of } \\
\text { cardiac disease (54) } \\
\text { Slow renal dysfunction (43) }\end{array}$ & $\begin{array}{l}\text { First-line desmoid tumor } \\
\text { treatment (55) } \\
\text { Long-term treatment } \\
\text { attenuates cystic fibrosis } \\
\text { (56) }\end{array}$ \\
\hline Side-effect & $\begin{array}{l}\uparrow L D L, \uparrow \text { HDL, } \uparrow \text { insulin } \\
\text { resistance }(57) \text { Higher risk of } \\
\text { sudden cardiac death }(58) \uparrow \\
\text { lipid peroxidation }(59,60)\end{array}$ & $\begin{array}{l}\text { Gastrointestinal bleeding } \\
(61) \text { Increased risk of spinal } \\
\text { fusion after sugery (62) } \\
\text { Increased risk of coronary } \\
\text { heart disease (63) Worsened } \\
\text { kidney function (64) }\end{array}$ \\
\hline
\end{tabular}

"Omega-3 low dose <1.2 g/d, high dose > $2 \mathrm{~g} / \mathrm{d}$. NSAIDs dose is various depending on the drug.

the human neutrophil transendothelial migration by competing for the leukotriene B4 receptors (BLT1) with LTB4 (67). Protectins are the other group of new pro-resolving and antiinflammatory lipid mediators, which are derived from DHA only (66). They block the immigration of T-cells, promote the T cell apoptosis, and reduce the potent inflammatory factor $\mathrm{TNF} \alpha$ (68).

Other than directly affecting the eicosanoid pathway, ALA, EPA, and DHA also helps to reduce pro-inflammatory cytokines, including TNF $\alpha$, IL-1, and IL-6 (30). These potent cytokines initiate the cascade of pro-inflammatory mediators, including cytokines, chemokines and adhesion molecules following injury. This leads to the high recruitment of immune cells, such as neutrophils, monocytes, $\mathrm{B}$ cells and T cells. In most acute and chronic inflammatory diseases, it has been shown that omega3 PUFA attenuates the inflammatory response by reducing the inflammatory hallmarks (30). In cardiac diseases, omega-3 PUFA can inhibit the secretion of lipopolysacchrides (LPS). This limits the initiation of LPS-induced inflammatory pathway, including NF- $\kappa \mathrm{B}$ and toll-like receptor 4 (TLR4) (69). Along with such inhibition of pro-inflammatory signaling, nitric oxide (NO) production increases (45). This leads to improved endothelial function (70).

Considering of the close relation between inflammation and oxidative stress, omega-3 PUFA can also lower oxidative stress through increased cellular antioxidant capacity. However, this result can only be reached with over $3.4 \mathrm{~g} /$ day EPA/DHA consumption (71). Having a high dose of omega-3 PUFA on the other hand can cause excess fatty acid accumulation, which potentially can also increase oxidative stress, given that omega-3 PUFAs have multiple double bonds amenable to oxidation.

\section{POTENTIAL RISKS OF OMEGA-3 PUFA SUPPLEMENTATION}

Inflammation exists to fight off infection or injury. Thus, while LGI may be perceived as detrimental, acute inflammation especially in the context of infection is a protective response that needs to be sustained at least for some time. In a chronic inflammatory state, such as rheumatoid arthritis (RA), EPA/DHA reduce RA inflammation and benefits the patient. However, the similar effects during infection or tumor surveillance can result in a negative health outcome (72-74). In 2005, IOM summarized that intake of 0.9-9.4 g/day of EPA and 0.6-6 g/day of DHA was linked to an impairment of immune responses. It is now known that DHA and EPA can both improve and impair host resistance to a number of pathogens $(75,76)$. These adverse outcomes of omega-3 intake were observed with bacterial, fungal and viral pathogen models (77). Given the potent anti-inflammatory effects of DHA and EPA, it is thus conceivable omega-3 PUFA can be both helpful or detrimental specific to the disease context. Moreover, like most nutrients or anti-inflammatory drugs, there is a potential for negative health effects under excess intakes.

\section{NSAIDs AND OMEGA-3 PUFA IN COMBINATION?}

An intriguing idea would be to use both low dose NSAID and long chain omega-3s like DHA/EPA in combination for prevention of cardiac and other LGI states. In theory, as both these classes of drugs act on the same COX/LOX pathway, the requirements/dosing of each might be lower due to their synergistic effects. The problem with such an approach is that long term safety of omega-3 supplementation in the pill form still remains unestablished in patients with various LGI states including CVD. With recent reports of long term ill effects of NSAIDs at the current dosing levels in cardiac patients, there is evidence that it might be risky to carry on such a trial for potential negative effects on coagulation (78).

In conclusion, the effectiveness of NSAIDs for acute inflammation has not translated to a safe strategy for long term prevention of CVD. Controversy also surrounds the long term impact of omega-3 PUFA as a preventative measure against chronic low grade inflammation (77). However, in patients unable to take NSAIDs in the long term due to GI or bleeding problems, due to the similarity in their mechanism of action, 
low dose omega-3 PUFA could be a substitute to prevent LGI associated with cardiovascular diseases.

\section{AUTHOR CONTRIBUTIONS}

JY wrote the paper. SG edited and revised the paper. Both authors read and approved the final manuscript.

\section{REFERENCES}

1. Epelman S, Liu PP, Mann DL. Role of innate and adaptive immune mechanisms in cardiac injury and repair. Nat Rev Immunol. (2015) 15:117-29. doi: $10.1038 /$ nri3800

2. Calder PC, Ahluwalia N, Brouns F, Buetler T, Clement K, Cunningham, K, et al. Dietary factors and low-grade inflammation in relation to overweight and obesity. Br J nutr. (2011) 106:S1-78. doi: 10.1017/S0007114511005460

3. Vane J, Botting R. Anti-inflammatory drugs and their mechanism of action. Inflamm Res. (1998) 47:78-87. doi: 10.1007/s000110050284

4. DeWitt DL, Meade EA, Smith WL. PGH synthase isoenzyme selectivity: the potential for safer nonsteroidal antiinflammatory drugs. Am J Med. (1993) 95:S40-44. doi: 10.1016/0002-9343(93)90396-7

5. Smith WL. The eicosanoids and their biochemical mechanisms of action. Biochem J. (1989) 259:315-324. doi: 10.1042/bj2590315

6. Calder PC. Long-chain polyunsaturated fatty acids and inflammation. Scand J Food Nutr. (2006) 50:54-61. doi: 10.1080/17482970601066389

7. Ivey KJ. Mechanisms of nonsteroidal anti-inflammatory drug-induced gastric damage: actions of therapeutic agents. Am J Med. (1988) 84:41-8. doi: 10.1016/0002-9343(88)90253-7

8. Vane J, Botting R. The mechanism of action of aspirin. Thromb Res. (2003) 110:255-8. doi: 10.1016/S0049-3848(03)00379-7

9. Aarons L, Clifton P, Fleming G, Rowland M. Aspirin binding and the effect of albumin on spontaneous and enzyme-catalysed hydrolysis. J Pharm Pharmacol. (1980) 32:537-43. doi: 10.1111/j.2042-7158.1980.tb12991.x

10. Don BR, Kaysen G. Poor nutritional status and inflammation: serum albumin: relationship to inflammation and nutrition. Semin Dialysis (2004) 17:432-7. doi: 10.1111/j.0894-0959.2004.17603.x

11. Wallace JL. Prostaglandins, NSAIDs, and gastric mucosal protection: why doesn't the stomach digest itself? Physiol Rev. (2008) 88:1547-65. doi: 10.1152/physrev.00004.2008

12. Musumba C, Pritchard D, Pirmohamed M. Cellular and molecular mechanisms of NSAID-induced peptic ulcers. Aliment Pharmacol Ther. (2009) 30:517-31. doi: 10.1111/j.1365-2036.2009.04086.x

13. Boardman P, Hart FD. Side-effects of indomethacin. Ann Rheum Dis. (1967) 26:127-132. doi: 10.1136/ard.26.2.127

14. Salvetti A, Arzilli F, Pedrinelli R, Beggi P, Motolese M. Interaction between oxprenolol and indomethacin on blood pressure in essential hypertensive patients. Eur J Clin Pharmacol. (1982) 22:197-201. doi: 10.1007/BF00545214

15. Rainsford K. Ibuprofen: pharmacology, efficacy and safety. Inflammopharmacology (2009) 17:275-342. doi: 10.1007/s10787-009-0016-X

16. Smith SC Jr, Allen J, Blair SN, Bonow RO, Brass LM, Fonarow GC, et al. AHA/ACC guidelines for secondary prevention for patients with coronary and other atherosclerotic vascular disease: update: endorsed by the National Heart, Lung, and Blood Institute. Circulation (2006) 113:2363-72. doi: 10.1161/CIRCULATIONAHA.106.174516

17. Graham I, Atar D, Borch-Johnsen K, Boysen G, Burell G, Cifkova R, et al. European guidelines on cardiovascular disease prevention in clinical practice: executive summary: fourth joint task force of the european society of cardiology and other societies on cardiovascular disease prevention in clinical practice (Constituted by representatives of nine societies and by invited experts). Eur Heart J. (2007) 28:2375-414. doi: 10.1093/eurheartj/ ehm316

18. Ikeda Y, Shimada K, Teramoto T, Uchiyama S, Yamazaki T, Oikawa S, et al. Low-dose aspirin for primary prevention of cardiovascular events in Japanese patients 60 years or older with atherosclerotic risk factors: a randomized clinical trial. JAMA (2014) 312:2510-20. doi: 10.1001/jama.2014.15690

\section{FUNDING}

Financial support for this article was provided by a Ph.D studentship from the China Scholarship Council to JY. SG is supported by a personnel award from the Michael Smith Foundation for Health Research and an operating grant from Diabetes Canada.

19. Guirguis-Blake JM, Evans CV, Senger CA, O'Connor EA, Whitlock EP, Aspirin for the primary prevention of cardiovascular events: a systematic evidence review for the u.s. preventive services task force. Ann Intern Med. (2016) 164:804-13. doi: 10.7326/M15-2113

20. De Caterina R, Ruigómez A, Rodríguez LA. Long-term use of antiinflammatory drugs and risk of atrial fibrillation. Arch Intern Med. (2010) 170:1450-5. doi: 10.1001/archinternmed.2010.305

21. Kirkby NS, Lundberg MH, Wright WR, Warner TD, Paul-Clark MJ, Mitchell JA. COX-2 protects against atherosclerosis independently of local vascular prostacyclin: identification of COX-2 associated pathways implicate Rgl1 and lymphocyte networks. PLoS ONE (2014) 9:e98165. doi: 10.1371/journal.pone.0098165

22. Varga Z, rafay ali Sabzwari S, Vargova V. Cardiovascular risk of nonsteroidal anti-inflammatory drugs: an under-recognized public health issue. Cureus (2017) 9:e1144. doi: 10.7759/cureus.1144

23. Bally M, Dendukuri N, Rich B, Nadeau L, Helin-Salmivaara A, Garbe E, et al. Risk of acute myocardial infarction with NSAIDs in real world use: bayesian meta-analysis of individual patient data. BMJ (2017) 357:j1909. doi: 10.1136/bmj.j1909

24. Shau WY, Chen HC, Chen ST, Chou HW, Chang CH, Kuo CW, et al. Risk of new acute myocardial infarction hospitalization associated with use of oral and parenteral non-steroidal anti-inflammation drugs (NSAIDs): a case-crossover study of Taiwan's National Health Insurance claims database and review of current evidence. BMC Cardiovasc Disord. (2012) 12:4. doi: 10.1186/1471-2261-12-4

25. Sundstrom J, Hedberg J, Thuresson M, Aarskog P, Johannesen KM, Oldgren J. Low-dose aspirin discontinuation and risk of cardiovascular events: a swedish nationwide, population-based cohort study. Circulation (2017) 136:1183-92. doi: 10.1161/CIRCULATIONAHA.117.028321

26. Endo J, Arita M. Cardioprotective mechanism of omega-3 polyunsaturated fatty acids. J cardiol. (2016) 67:22-7. doi: 10.1016/j.jjcc.2015.08.002

27. Masterton G, Plevris J, Hayes P. omega-3 fatty acids-a promising novel therapy for non-alcoholic fatty liver disease. Aliment Pharmacol Ther. (2010) 31:679-92. doi: 10.1111/j.1365-2036.2009.04230.x

28. Innis SM. Dietary omega 3 fatty acids and the developing brain. Brain Res. (2008) 1237:35-43. doi: 10.1016/j.brainres.2008.08.078

29. Lee S, Kim HJ, Chang KC, Baek JC, Park JK, Shin JK, et al. DHA and EPA down-regulate COX-2 expression through suppression of NF- $\kappa$ B activity in LPS-treated human umbilical vein endothelial cells. Korean J Physiol Pharmacol. (2009) 13:301-7. doi: 10.4196/kjpp.2009.13.4.301

30. Simopoulos AP. Omega-3 fatty acids in inflammation and autoimmune diseases. J Am Coll Nutr. (2002) 21:495-505. doi: 10.1080/07315724.2002.10719248

31. Vane J, Botting R. Mechanism of action of anti-inflammatory drugs. Scandinavian J Rheumatol. (1996) 25:9-21. doi: 10.3109/03009749609097226

32. Illingworth DR, Harris WS, Connor WE. Inhibition of low density lipoprotein synthesis by dietary omega-3 fatty acids in humans. Arteriosclerosis (1984) 4:270-5.

33. Rho YH, Oeser A, Chung CP, Milne GL, Stein CM. Drugs used in the treatment of rheumatoid arthritis: relationship between current use and cardiovascular risk factors. Arch Drug Inf. (2009) 2:34-40. doi: 10.1111/j.1753-5174.2009.00019.x

34. Bhosale UA, Quraishi N, Yegnanarayan R, Devasthale D. A cohort study to evaluate cardiovascular risk of selective and nonselective cyclooxygenase inhibitors (COX-Is) in arthritic patients attending orthopedic department of a tertiary care hospital. Niger Med J. (2014) 55:417-22. doi: $10.4103 / 0300-1652.140386$ 
35. Geleijnse JM, Giltay EJ, Grobbee DE, Donders AR, Kok FJ. Blood pressure response to fish oil supplementation: metaregression analysis of randomized trials. J Hypertens. (2002) 20:1493-9. doi: 10.1097/00004872-200208000-00010

36. Johnson AG, Nguyen TV, Day RO. Do nonsteroidal anti-inflammatory drugs affect blood pressure? A meta-analysis. Ann Intern Med. (1994) 121:289-300. doi: 10.7326/0003-4819-121-4-199408150-00011

37. Snowden S, Nelson R. The effects of nonsteroidal anti-inflammatory drugs on blood pressure in hypertensive patients. Cardiol Rev. (2011) 19:184-91. doi: 10.1097/CRD.0b013e31821ddcf4

38. Endres S, Ghorbani R, Kelley VE, Georgilis K, Lonnemann G, van der Meer JW, et al. The effect of dietary supplementation with $n-3$ polyunsaturated fatty acids on the synthesis of interleukin-1 and tumor necrosis factor by mononuclear cells. N Engl J Med. (1989) 320:265-71. doi: 10.1056/NEJM198902023200501

39. Adkins Y, Kelley DS. Mechanisms underlying the cardioprotective effects of omega-3 polyunsaturated fatty acids. J Nutr Biochem. (2010) 21:781-92. doi: 10.1016/j.jnutbio.2009.12.004

40. Berg J, Fellier H, Christoph T, Grarup J, Stimmeder D. The analgesic NSAID lornoxicam inhibits cyclooxygenase (COX)-1/-2, inducible nitric oxide synthase (iNOS), and the formation of interleukin (IL)-6 in vitro. Inflamm Res. (1999) 48:369-79. doi: 10.1007/s000110050474

41. Mori TA, Beilin LJ. Omega-3 fatty acids and inflammation. Curr Atheroscler Rep. (2004) 6:461-7. doi: 10.1007/s11883-004-0087-5

42. Li H, Hortmann M, Daiber A, Oelze M, Ostad MA, Schwarz PM, et al. Cyclooxygenase 2-selective and nonselective nonsteroidal antiinflammatory drugs induce oxidative stress by up-regulating vascular NADPH oxidases. J Pharmacol Exp Ther. (2008) 326:745-53. doi: 10.1124/jpet.108. 139030

43. Donadio JV, Larson TS, Bergstralh EJ, Grande JP, Group MNC. A randomized trial of high-dose compared with low-dose omega-3 fatty acids in severe $\operatorname{IgA}$ nephropathy. J Am Soc Nephrol. (2001) 12:791-9.

44. Reda DM, Abd-El-Fatah NK, Omar Tel-S, Darwish OA. Fish oil intake and seizure control in children with medically resistant epilepsy. N Am J Med Sci. (2015) 7:317. doi: 10.4103/1947-2714.161248

45. Tajalizadekhoob Y, Sharifi F, Fakhrzadeh H, Mirarefin M, Ghaderpanahi M, Badamchizade $Z$, etal. The effect of low-dose omega 3 fatty acids on the treatment of mild to moderate depression in the elderly: a double-blind, randomized, placebo-controlled study. Eur Arch Psychiatry Clin Neurosci. (2011) 261:539-49. doi: 10.1007/s00406-011-0191-9

46. Jain S, Gaiha M, Bhattacharjee J, Anuradha S. Effects of low-dose omega3 fatty acid substitution in type-2 diabetes mellitus with special reference to oxidative stress-a prospective preliminary study. J Assoc Physicians India (2002) 50:1028-33.

47. Ridker PM, Cook NR, Lee IM, Gordon D, Gaziano JM, Manson JE, et al. A randomized trial of low-dose aspirin in the primary prevention of cardiovascular disease in women. N Engl J Med. (2005) 352:1293-304. doi: 10.1056/NEJMoa050613

48. Weisman SM, Graham DY. Evaluation of the benefits and risks of low-dose aspirin in the secondary prevention of cardiovascular and cerebrovascular events. Arch Intern Med. (2002) 162:2197-202. doi: 10.1001/archinte.162.19.2197

49. Jain AK, Ryan JR, McMahon FG, Kuebel J, Walters P, Noveck C, Analgesic efficacy of low-dose ibuprofen in dental extraction pain. Pharmacotherapy (1986) 6:318-22. doi: 10.1002/j.1875-9114.1986.tb03494.x

50. Bradley JD, Brandt KD, Katz BP, Kalasinski LA, Ryan SI. Comparison of an antiinflammatory dose of ibuprofen, an analgesic dose of ibuprofen, and acetaminophen in the treatment of patients with osteoarthritis of the knee. N Engl J Med. (1991) 325:87-91. doi: 10.1056/NEJM1991071132 50203

51. Yao M, Zhou W, Sangha S, Albert A, Chang AJ, Liu TC, et al. Effects of nonselective cyclooxygenase inhibition with low-dose ibuprofen on tumor growth, angiogenesis, metastasis, and survival in a mouse model of colorectal cancer. Clin Cancer Res. (2005) 11:1618-28. doi: 10.1158/1078-0432.CCR-04-1696

52. Ment LR, Ehrenkranz RA, Duncan CC, Scott DT, Taylor KJ, Katz KH, et al. Low-dose indomethacin and prevention of intraventricular hemorrhage: a multicenter randomized trial. Pediatrics (1994) 93:543-550.
53. Kremer JM, Lawrence DA, Petrillo GF, Litts LL, Mullaly PM, Rynes RI, et al. Effects of high-dose fish oil on rheumatoid arthritis after stopping nonsteroidal antiinflammatory drugs clinical and immune correlates. Arthritis Rheum. (1995) 38:1107-14. doi: 10.1002/art.1780380813

54. Casula M, Soranna D, Catapano AL, Corrao G. Long-term effect of high dose omega-3 fatty acid supplementation for secondary prevention of cardiovascular outcomes: a meta-analysis of randomized, double blind, placebo controlled trials. Atheroscler Suppl. (2013) 14:243-51. doi: 10.1016/S1567-5688(13)70005-9

55. Hansmann A, Adolph C, Vogel T, Unger A, Moeslein G. High-dose tamoxifen and sulindac as first-line treatment for desmoid tumors. Cancer (2004) 100:612-20. doi: 10.1002/cncr.11937

56. Konstan MW, Byard PJ, Hoppel CL, Davis PB. Effect of high-dose ibuprofen in patients with cystic fibrosis. N Engl J Med. (1995) 332:848-54. doi: 10.1056/NEJM199503303321303

57. Godeny P, M.Lozovoy AB, Dichi JB, Dichi I. Effect of n-3 fatty acids in glycemic and lipid profiles, oxidative stress and total antioxidant capacity in patients with the metabolic syndrome. Arq Bras Endocrinol Metabol. (2010) 54:463-469.

58. Burr ML, Ashfield-Watt P, Dunstan F, Fehily A, Breay P, Ashton T, et al. Lack of benefit of dietary advice to men with angina: results of a controlled trial. Eur J Clin Nutr. (2003) 57:193-200. doi: 10.1038/sj.ejcn. 1601539

59. Allard JP, Kurian R, Aghdassi E, Muggli R, Royall D. Lipid peroxidation during $\mathrm{n}-3$ fatty acid and vitamin $\mathrm{E}$ supplementation in humans. Lipids (1997) 32:535-41. doi: 10.1007/s11745-997-0068-2

60. Saito M, Kubo K. Relationship between tissue lipid peroxidation and peroxidizability index after $\alpha$-linolenic, eicosapentaenoic, or docosahexaenoic acid intake in rats. Br J Nutr. (2003) 89:19-28. doi: 10.1079/BJN2002731

61. Jick H. Risk of upper gastrointestinal bleeding and perforation associated with individual non-steroidal anti-inflammatory drugs. Lancet (1994) 343:769-72. doi: 10.1016/S0140-6736(94)91843-0

62. Reuben SS, Ablett D, Kaye R. High dose nonsteroidal anti-inflammatory drugs compromise spinal fusion. Can J Anesth. (2005) 52:506-12. doi: 10.1007/BF03016531

63. Ray WA, Stein CM, Daugherty JR, Hall K, Arbogast PG, Griffin MR. COX-2 selective non-steroidal anti-inflammatory drugs and risk of serious coronary heart disease. Lancet (2002) 360:1071-3. doi: 10.1016/S0140-6736(02)11131-7

64. Whelton A, Hamilton CW. Nonsteroidal anti-inflammatory drugs: effects on kidney function. J Clin Pharmacol. (1991) 31:588-98. doi: 10.1002/j.1552-4604.1991.tb03743.x

65. Maroon JC, Bost JW. $\omega-3$ Fatty acids (fish oil) as an anti-inflammatory: an alternative to nonsteroidal anti-inflammatory drugs for discogenic pain. Surg Neurol. (2006) 65:326-31. doi: 10.1016/j.surneu.2005.10.023

66. Serhan CN, Chiang N, Van Dyke TE. Resolving inflammation: dual antiinflammatory and pro-resolution lipid mediators. Nat Rev Immunol. (2008) 8:349. doi: $10.1038 /$ nri2294

67. Goldman D, Pickett W, Goetzl E. Human neutrophil chemotactic and degranulating activities of leukotriene B5 (LTB5) derived from eicosapentaenoic acid. Biochem Biophys Res Commun. (1983) 117:282-8. doi: 10.1016/0006-291X(83)91572-3

68. Ariel A, Li PL, Wang W, Tang WX, Fredman G, Hong S, et al. The docosatriene protectin D1 is produced by TH2 skewing and promotes human T cell apoptosis via lipid raft clustering. J Biolog Chem. (2005) 280:43079-86. doi: 10.1074/jbc.M509796200

69. Norris PC, Dennis EA. Omega-3 fatty acids cause dramatic changes in TLR4 and purinergic eicosanoid signaling. Proc Natl Acad Sci USA. (2012) 109:8517-22. doi: 10.1073/pnas.1200189109

70. Dharmashankar K, Widlansky ME. Vascular endothelial function and hypertension: insights and directions. Curr Hypertens Rep. (2010) 12:448-55. doi: 10.1007/s11906-010-0150-2

71. Block RC, Dier U, CalderonArtero P, Shearer GC, Kakinami L, Larson MK, et al. The effects of EPA+ DHA and aspirin on inflammatory cytokines and angiogenesis factors. World J Cardiovasc Dis. (2012) 2:14-19. doi: $10.4236 /$ wjcd.2012.21003

72. Oarada M, Tsuduki T, Suzuki T, Miyazawa T, Nikawa T, Hongquan G, et al. Dietary supplementation with docosahexaenoic acid, but not with eicosapentaenoic acid, reduces host resistance to 
fungal infection in mice. Biochim Biophys Acta (2003) 1622:151-60. doi: 10.1016/S0304-4165(03)00136-3

73. Byleveld PM, Pang GT, Clancy RL, Roberts DC. Fish oil feeding delays influenza virus clearance and impairs production of interferon-gamma and virus-specific immunoglobulin A in the lungs of mice. J Nutr. (1999) 129:328-35. doi: 10.1093/jn/129.2.328

74. Fritsche KL, Shahbazian LM, Feng C, Berg JN. Dietary fish oil reduces survival and impairs bacterial clearance in $\mathrm{C} 3 \mathrm{H} / \mathrm{Hen}$ mice challenged with Listeria monocytogenes. Clin Sci (Lond). (1997) 92:95-101. doi: 10.1042/cs09 20095

75. Anderson M, Fritsche KL. $(n-3)$ Fatty acids and infectious disease resistance. J Nutr. (2002) 132:3566-76. doi: 10.1093/jn/132. 12.3566

76. Calder PC, Grimble RF. Polyunsaturated fatty acids, inflammation and immunity. Eur J Clin Nutr. (2002) 56 Suppl. 3:S14-9. doi: $10.1038 /$ sj.ejcn. 1601478

77. Fenton JI, Hord NG, Ghosh S, Gurzell EA. Immunomodulation by dietary long chain omega-3 fatty acids and the potential for adverse health outcomes. Prostaglandins Leukot Essent Fatty Acids (2013) 89:379-90. doi: 10.1016/j.plefa.2013.09.011

78. Block RC, Kakinami L, Jonovich M, Antonetti I, Lawrence P, Meednu $\mathrm{N}$, et al. The combination of EPA+DHA and low-dose aspirin ingestion reduces platelet function acutely whereas each alone may not in healthy humans. Prostaglandins Leukot Essent Fatty Acids (2012) 87:143-51. doi: 10.1016/j.plefa.2012.08.007

Conflict of Interest Statement: The authors declare that the research was conducted in the absence of any commercial or financial relationships that could be construed as a potential conflict of interest.

Copyright (C) 2018 Ye and Ghosh. This is an open-access article distributed under the terms of the Creative Commons Attribution License (CC BY). The use, distribution or reproduction in other forums is permitted, provided the original author(s) and the copyright owner(s) are credited and that the original publication in this journal is cited, in accordance with accepted academic practice. No use, distribution or reproduction is permitted which does not comply with these terms. 